\title{
A review of individual and systemic risk measures in terms of applicability for banking regulations
}

\author{
Katarzyna Sum ${ }^{1}$
}

\begin{abstract}
The latest financial crisis has exposed substantial weaknesses in the bank risk models used by national regulators as well as the Basel Accords. The study is aimed at presenting the evolution and critique of risk measures and risk models in banking, with a special focus on the dynamically developing area of systemic risk measures. A discussion of the features of the respective measures allows us to draw conclusions for banking regulations based on the analyzed models and to present the main challenges for regulators in terms of bank risk measurement. The study shows that substantial challenges for regulators include compensating for the drawbacks of the Value at Risk (VaR) and expected shortfall risk models, resolving the pro-cyclicality in risk modeling, improving the techniques of stress testing, and addressing the fallacy of composition in banking (i.e., to model risk from a systemic point of view and not only from the perspective of an individual bank). As the discussion concerning proper risk measurement in regulatory frameworks, such as the Basel Accord or the European Banking Authority's (EBA) rules is in progress, the topic seems to be of particular importance; moreover, measures of systemic risk are not yet a subject of regulation.
\end{abstract}

KEY WORDS: $\quad$ bank risk, risk measures, risk models, systemic risk

JEL Classification: G2, F3

${ }^{1}$ Warsaw School of Economics - Chair of International Finance, Poland

\section{Introduction}

For decades, bank risk modeling has been a challenge for managers of financial institutions and regulating authorities. The latest financial crisis has unleashed substantial weaknesses of the risk models used by national supervisors and the Basel Accords. These models are too arbitrary to evaluate the risk profiles of large banks. As such, they are prone to pro-cyclicality, which

Correspondence concerning this article should be addressed to: Katarzyna Sum, Warsaw School of Economics - Chair of International Finance, ul. Madalińskiego 6/8, 02-513 Warszawa, Poland. T: 22 5649365. E-mail:ksum@sgh.waw.pl has contributed to incorrect risk measurement. Banking regulations derived from these models focus solely on individual bank risk without regard to the fallacy of composition problem; that is, even if individual banks function well, the banking system can fail. Hence, the focus of post-crisis regulations has shifted from a micro-prudential approach of banking supervision to a macro-prudential one.

While measuring individual bank risk is a complex process in itself, the difficulties in estimation and modeling increase dramatically when one takes systemic bank risk into account. This study is aimed at presenting the evolution and critique of risk measures 
in banking, with a special focus on the dynamically developing area of systemic risk measurement. The discussion of the features of each measure allows to draw conclusions for banking regulations that are based on the mentioned models and to present the main challenges for regulators in terms of bank risk measurement. Because the measures capable of counteracting systemic risk are currently not a subject of regulation, this topic seems to be of particular importance.

The paper is structured as follows: the first section reviews the individual bank risk measures, the second presents the risk models based on the mentioned measures, and the third section focuses on systemic risk measurement.

\section{Review of risk measures}

Banking risk includes credit risk, market risk (i.e., the risk of price changes), and operational risk (i.e., related to the banks general activity). The measurement and quantification of the various risk types has been a substantial challenge for academics, bank managers, and regulators.

In most cases, risk measures are defined as functions of random variables, such as portfolio losses or returns. These types of measures require an arbitrary choice of the time horizon over which one analyses the losses and returns, as well as the assumed probability distribution (Basel Committee for Banking Supervision [BCBS], 2011). In contrast, risk measures that provide general information about the bank's financial soundness (e.g., the z-score) are based on accounting information and do not require assumptions about the distribution of losses. Determining which risk measurement to use depends on a number of factors, such as the simplicity of calculation, the mathematical properties of the measure, the ability to attribute risk to individual portfolio components, the ability to backtest, and the objectives of regulators/managers (BCBS, 2011).

The most common measure of bank risk is the Value at Risk (VaR). The theoretical foundations for VaR are based on the portfolio theory of Markowitz. VaR is defined as the maximum value of the loss on a given portfolio for an assumed probability of the loss over a specific time horizon. In other words, VaR defines how much money an institution should set aside to counteract a predicted loss. The computation of $\mathrm{VaR}$ is aimed at preventing a liquidity crisis triggered by a loss in the case of a low probability event. The term Value at Risk was first used officially by J. P. Morgan in 1995, referencing their RiskMetrics database, which enables public access to data on the variances of and covariances across various asset classes. It has been used by banks and regulators over the last two decades (Damodaran, 2010).

While there is no definition of how to compute VaR, its estimation requires assumptions about the profit and loss density function. To estimate the potential loss on a portfolio, the probability distributions of individual risks, as well as their correlation and their effect on the value of the potential loss, have to be defined, resulting in arbitrary risk modeling. Three solutions are applied to address this problem: estimation based on past values of the parameters, Monte Carlo methods, which require an assumption about the distribution of the portfolio values, and analytic methods, which are based on assumptions about the return distribution parameters (Damodaran, 2010).

The VaR measure has many drawbacks. First, it assumes a normal distribution of the values without accounting for fat tails. Thus, despite this fact the VaR concept is regarded as the worst case scenario, regulators and managers cannot focus on extreme events, which may result in excessive risk taking. Second, even if the assumption of the distribution is correct, another problem is the non-stationarity of variances and covariances across assets (BCBS, 2011). Third, the classical VaR assumes a linear relationship between risk and portfolio positions, which does not hold when derivate instruments are included in the portfolio. Finally, another drawback is the narrow focus on market risk.

Prior to the recent financial crisis, the use of VaR models contributed to the build-up of risk in the banking sector, as the models gave managers and regulators a false sense of security. A crucial criticism is that while $\mathrm{VaR}$ is the worst case scenario, it does not account for situations where the loss exceeds the VaR. The concept does not offer any solutions beyond the threshold of VaR, nor are there any implications regarding the distribution of losses beyond the VaR level. A possible solution to this problem is the concept of Conditional Value at risk (CVaR), also known as expected shortfall. The expected shortfall concept has substantial theoret- 
Table 1.

\begin{tabular}{ll}
\hline VaR & Expected Shortfall/ CVaR \\
\hline Abstracts from extreme events & Accounts for extreme events \\
Inferior mathematical properties & Superior mathematical properties \\
Backtesting possibility & No possibility of backtesting \\
Robust to estimation errors & Prone to estimation errors- accuracy of tail modeling is crucial \\
\hline
\end{tabular}

ical foundations (Acerbi \& Tasche, 2002; Rockafellar \& Uryasev, 2002; Yamai \& Yoshiba, 2005). Its popularity among bank managers and regulators has increased. Because of its coherence, the Basel Committee included this concept, rather than the VaR used over the last decade, in its new regulatory framework Basel III (Chen, 2014).

The expected shortfall assumes losses in the tails of the distribution function i.e., beyond the value of VaR. The term conditional value at risk was introduced by Rockafellar and Uryasev in 2000 (Rockafellar \& Uryasev, 2002). Larsen, Mausser and Uryasev (2002) define it as a weighted average of the VaR and losses exceeding the VaR. The expected shortfall is the expected loss on a given portfolio in the worst case scenario i.e., provided that the loss exceeds a given value. Hence, the evaluation of an investment is more conservative than in the case of VaR. This approach helps counteract excessive risk taking by managers. Compared to VaR, CVaR has superior mathematical properties. It also mitigates the effect of the arbitrary choice of a single confidence level on estimated losses (BCBS, 2011).

A drawback of CVaR is that it is more sensitive to estimation errors than VaR i.e., CVaR's accuracy depends largely on the accuracy of tail modeling. In the event when the tail modeling is inaccurate, the mixed CVaR concept can be applied. In the mixed CVaR concept, instead of penalizing extreme tail losses, different weights are attributed to different parts of the distribution. One should take into account that historical data may not carry the necessary information about the tails. In this case, adjustment of the tail modeling may be needed (Rockafellar \& Uryasev, 2002). Another drawback of expected shortfall is the inability to backtest the model. In contrast to the VaR concept, expected shortfall forecasts cannot be verified through comparison with historical data (Chen, 2014). The main differences between $\mathrm{VaR}$ and $\mathrm{CVaR}$ are depicted in Table 1.

The economic literature improves upon the expected shortfall concept by proposing new spectral risk measures that generalize expected shortfall (BCBS, 2011). In addition to having desirable mathematical properties, these measures can also be adapted to investor behavior. The concept of generalized spectral measures implies that banks will be less risk averse towards small losses while more risk averse towards large losses. The highest weights are attributed to losses in cases where banks are unwilling to raise additional capital to absorb the loss. An advantage of general spectral measures is that, in contrast to VaR and expected shortfall, the outcome of the model does not depend on a single confidence level. Instead, the changes in the loss distribution will allow the risk measure to adapt (BCBS, 2011).

Another attempt to improve the risk measurement is the concept of the stressed value at risk. The measure has been proposed by the Basel Committee in 2009 within the so called Basel 2.5 framework. The main trigger of this concept is the financial crisis, during which the losses in banks' trading books largely exceeded the VaR-based capital requirements. In a stressed VaR framework, the value at risk is computed with the assumption of "a continuous 12-month period of significant financial stress" (BCBS, 2009b, p. 14).

The stressed VaR shows that current market conditions may lead to risk underestimation during times of financial stress (BCBS, 2011). Its purpose is to counteract the pro-cyclicality in capital provisioning. A prob- 
lem related to the stressed VaR is the calibration of the reference period (European Banking Authority [EBA], 2012). According to the Basel Committee, the methodology banks use to identify a stressed period that is relevant to their current portfolios is either formulaic or judgment-based, which enables them to make arbitrary choices. It has been stressed in the literature that past events and crises are not a good indicator of future bank performance (Chen, 2014). During a financial crisis, the volatility of market prices rises to extreme levels, which causes the correlation of returns used in the VaR methodology to deviate from historical values. The concept of stressed VaR lacks theoretical underpinnings; consequently, its discussion in the academic literature is sparse.

The Basel Committee has tried to introduce a risk measure that would be resistant to fragility during periods of extreme financial stress and easily backtested. In these terms, the concepts proposed in Basel 2.5 and in Basel III are contradictory; they highlight the conflict between the elicit VaR and coherent expected shortfall. (Chen, 2014). Alternative risk measures to $\mathrm{VaR}$ are considered to be technological leaders; as a consequence, their popularity in the banking sector has increased (BCBS, 2011).

\section{Review of risk models in banking regulations}

The risk measures discussed are the basis for risk modeling for financial institutions and regulating agencies. A large number of risk models are derived from the Basel Accords.

The first Basel Accord from 1988 focuses on credit risk models attributed to the respective types of asset groups. The changes in the scope of banking activity enabled by deregulation make it apparent that regulators have to account for both credit and market risk. The Market Risk Amendment from 1996 introduces additional capital charges for banks' assets that are exposed to market risk. The capital requirements have been computed on the basis of two alternative models: the standardized approach or internal bank risk models. The former applies ready formulas for capital charges drawn from regulations, the latter uses VaR models that have been developed by the banks themselves and approved by the supervisory authorities. While the standardized approach is used primarily by small banks with limited exposure to market risk, it can also be applied in the event of internal model failure. Since the expansion of credit exposures securitization renders the construction of the regulatory trading book obsolete, the Market Risk Amendment from 1996 also specifies the risk charges to instruments in the banks' trading books. The risk charges do not adequately capture the market risk exposure of the assets. This has led to further reforms of the Basel framework, including the introduction of an incremental default risk charge to VaR models (BCBS, 2012).

One of the weaknesses of the Basel I framework is the various treatment of trading and banking books, particularly the inclusion of assets that are exposed to credit risk in the trading book. The regulations state how to estimate the correlations between different asset values to determine portfolio risk. In the case of the credit risk in the banking book, asset value correlations are derived from regulations, even for banks using internal models.

Moreover, the framework does not specify when to use the standardized approach or the model based approach. Even worse, although they did not necessarily work, the internal models cannot be changed during times of financial turmoil. Additionally, the measurement of risk raises some concerns. The standardized approach suffers from the portfolio invariance problem i.e., diversified portfolios are assigned the same risk weights as concentrated ones. Moreover, the standardized approach does not capture the risk exposure to complex instruments. On the other hand, the internal model approach is based on 10- day VaR i.e., it focuses on day-to-day risk exposures and did not account for tail events. The arbitrary choice of the models by individual banks may have limited individual bank risk, but is not equipped to counteract systemic risk (BCBS, 2012).

In 2004, Basel II strengthens the framework for risk models. The supervisory agencies are required to monitor both individual bank risk and systemic risk. Moreover, liquidity risk, concentration risk, and legal risk becomes the focus of supervisors.

Basel II maintains the basic features of Basel I, which has many drawbacks; one of which is the pro-cyclicality of risk assessment. The standardized approach uses external ratings which tend to be pro- 

resulting from mark-to-market accounting or the increased leverage in times of economic expansion. One of the proposed solutions is the estimation of the probability of default over a longer time horizon and the introduction of forward-looking, dynamic provisioning based on expected, rather than current, losses. The Committee also proposes bank capital deductions in cases of provision shortfall (Blundell- Wignall \& Atkinson, 2010).

A commonly criticized element of the Basel III framework is the application of various risk measures that may lead to varied results in terms of capital levels. Moreover, differences in the outcomes of the standardized and model based approaches still exist. Blundell-Wignall and Atkinson (2010) find that while Basel III does not address the main problems of the risk-weighting approach in the calculation of capital requirements, it improves some aspects of the risk management process by introducing leverage ratios, countercyclical measures, and the promotion of settling derivatives to clearing houses. The authors stress that Basel III does not solve the problem of portfolio invariance, as there are no additional capital requirements for concentrated portfolios. Moreover, they stress that the risk modeling is too linear- it reflects a single global risk factor instead of local factors. As we have seen in the subprime crisis, shocks tend to originate locally and spread globally (Slovik, 2012).

An additional challenge for regulators is the aggregation of risk types into risk indicators that allow for the formulation of capital requirements. One way to do this is to take the sum of the computed capital requirements for credit, market, and operational risk. This approach ignores portfolio invariance i.e., it does not account for diversification benefits. Another way is to estimate all the risks within an integrated framework that accounts for possible correlations and interactions (BCBS, 2011).

These empirical models are used for regulatory purposes and are abstract from the theoretically funded models prevalent in academic literature. Popular models that assess bank risk are accounting-based models (Altman, 1968; Ohlson, 1980) or the structural distance to default model (Merton, 1974). The academic models rely on the cost of debt, rather than default data, to assess the bankruptcy risk. The rationale behind this approach is that some banks never experi- ence bankruptcy. In addition, the lag between estimated and actual default can differ among banks such that quantifying default data may be problematic (Mansi, Maxwell \& Zhang 2010).

The historically most significant model used for assessment of financial distress is the distance to default model (Merton 1974). The model extends the option pricing formula to predict company defaults. An advantage of this model is that it is not sensitive to the leverage ratio of other models that are aimed at estimating the probability of default (Mansi et al. 2010). Gropp, Vesala and Vulpes (2006) show that the distance to default measure outperforms other indicators of risk in predicting bank defaults in Europe. Moreover, the Financial Stability Board stresses the importance of this measure in determining systemically important banks (Vallascas \& Keasey, 2012). While it does not account for tail events, the distance to default measure is appropriate for modeling central dependence. De Jonghe (2010) shows that risk indicators of tail dependence and central dependence may lead to substantially different outcomes. To measure bank risk in a stressed environment the literature proposes the concept of exceedances, which are defined as extreme increases of bank risk that are proxied by the daily changes of the distance to default measures (Vallascas \& Keasey 2012).

This model refers to individual bank risk; it can also be used to model systemic risk. This issue is discussed in the next section.

\section{Systemic risk measures}

Risk measurement at the individual bank level as the basis for computing regulatory capital charges can lead to an increase of systemic risk in the banking sector. Banks do not consider the linkages of portfolios within the system; they also underestimate the risk that increases during times of economic expansion. This leads to pro-cyclicality and high correlation of asset returns that amplifies in boom and bust cycles (BCBS, 2011).

Systemic risk occurs if many institutions fail simultaneously. Even if the system consists of individually sound institutions, exogenous events may trigger the instability of the system and cause these institutions to fail. This situation is described by the term "fallacy of composition". 
Following Danielsson, Shin and Zigrand (2013) one can define systemic risk as the sum of the risk of market volatility resulting from fundamental changes and the endogenous feedback of market participants i.e., trading patterns. Systemic risk is endogenous because while it depends on the behavior of market participants, this behavior depends on the perceived risk. If market players anticipate higher risk in the future, they will act upon this assumption, which contributes to market volatility. Patro, Qi, and Sun (2013) depict systemic risk as the probability of a broad-based breakdown of the financial system triggered by a systemic event e.g., the failure of a large financial institution. According to Adrian and Brunnemeier (2011) systemic risk consists of two elements: the risk which builds up during credit booms at times when perceived risk level is low and the spillover effects that amplify the shocks which occur during crises.

The economic literature identifies two basic ways of quantifying systemic risk from both macroeconomic and microeconomic points of view (Vallascas \& Keasey, 2012). The macroeconomic perspective focuses on the contribution of each individual institution to the systemic risk. The microeconomic approach to measuring systemic risk focuses on how individual banks react to systemic shocks. These two approaches use various risk measures.

Table 2 presents an overview of systemic risk measures applied in the literature as well as the attribution method of systemic risk to individual institutions. Due to their importance for banking regulatory frameworks, the factors contributing to systemic risk for a majority of the studies are also listed.

From the overview presented in Table 2, one can conclude that measuring systemic risk has a number of difficulties. First of all, it requires high frequency data concerning stock returns, stock option prices, or CDS spreads of banks, i.e., data which is not always available for large banks samples, especially during times of crises (Iyer \& Peydro, 2009). The high frequency of the data is needed to ensure the quick reactivity of the measure to market movements. Moreover, because the systemic risk measures serve as early warning indicators, they should have forward looking features, i.e., they should be based on detailed, properly extracted information from derivative markets.
Another problem is the determination of excessive systemic risk. The cited studies do not provide an answer of how to evaluate the proposed risk measures in terms of their impact on banking system instability. Systemic risk always exists and it is not the task of regulators to eliminate it. The focus of systemic risk analysis should not be on the level of systemic risk, rather, it should focus on the changes in the level over time (Patro et al., 2013).

A further difficulty is defining the factors of systemic risk to formulate proper regulations. While the studies point to various factors that contribute to systemic risk, there is no consensus as to which factors are domineering. A commonly held view is that bank size and the increase in non-traditional banking activities enhance systemic risk (de Jonghe, 2010). Because of large common exposures, big banks contribute to systemic risk more than small banks; moreover, the involvement of banks in activities other than deposit taking and lending enhances the transfer of risk from market segments that are not a subject of deposit insurance. The topic of systemic risk factors is widely researched and at the center of an intense debate among economists.

A very important feature of systemic risk that has to be considered is its endogeneity. The endogenous risk mechanism is as follows: a negative piece of information causes a decrease in capitalization or an increase in price volatility, which causes market participants to minimize their exposure to risk. An endogenous feedback loop occurs if this deterioration of financial conditions increases the risk aversion, which further worsens the financial conditions (Danielsson et al., 2013). The implication of endogeneity for systemic risk measurement is that the observed volatility should be modelled as two separate elements: the exogenous volatility and endogenous volatility while accounting for the multiplier effect in the latter element caused by the aforementioned feedback loop.

A problem in the application of the mentioned systemic risk measures and models for regulatory purposes arises because a large part of the measures is based on academic, theoretical models that have not been prevalent in regulatory practices. An additional challenge for regulators is the introduction of this new approach in the current framework. 
Table 2.

\begin{tabular}{|c|c|c|c|}
\hline Authors & Systemic risk measure & $\begin{array}{l}\text { Systemic risk attribution to } \\
\text { individual institutions }\end{array}$ & $\begin{array}{l}\text { Systemic risk } \\
\text { determinants }\end{array}$ \\
\hline Acharya et al. (2010) & $\begin{array}{l}\text { Marginal expected shortfall- the } \\
\text { average return of each institution, } \\
\text { based on high frequency data, } \\
\text { measured over the worst } 5 \% \text { of the } \\
\text { sample period. }\end{array}$ & $\begin{array}{l}\text { Systemic expected shortfall- the } \\
\text { propensity of an institution to be } \\
\text { undercapitalized when the whole } \\
\text { system is undercapitalized. }\end{array}$ & $\begin{array}{l}\text { Leverage, } \\
\text { expected loss. }\end{array}$ \\
\hline $\begin{array}{l}\text { Acharya, Engle, \& } \\
\text { Richardson (2012) }\end{array}$ & $\begin{array}{l}\text { Capital shortfall based on equity } \\
\text { returns. }\end{array}$ & $\begin{array}{l}\text { Capital shortfall calculated via } \\
\text { weighting assets by long run } \\
\text { marginal expected shortfall and } \\
\text { constant book values of debt. }\end{array}$ & $\begin{array}{l}\text { Systemically } \\
\text { risky assets, } \\
\text { leverage. }\end{array}$ \\
\hline $\begin{array}{l}\text { Adrian } \\
\text { \& Brunnermeier } \\
\text { (2011) }\end{array}$ & $\begin{array}{l}\text { CovaR, the value at risk of the whole } \\
\text { system conditional on the distress } \\
\text { of single institutions. Tail covariation } \\
\text { between the risk of single institutions } \\
\text { and the whole system based on high } \\
\text { and low frequency data. }\end{array}$ & $\begin{array}{l}\text { The difference between CoVaR } \\
\text { of an institution in distress and } \\
\text { CoVaR in the median state of the } \\
\text { institution. }\end{array}$ & $\begin{array}{l}\text { Size, leverage, } \\
\text { maturity mismatch. }\end{array}$ \\
\hline $\begin{array}{l}\text { Bartram, Brown \& } \\
\text { Hund (2007) }\end{array}$ & $\begin{array}{l}3 \text { measures of systemic risk: } \\
\text { 1. Equity returns of banks with no direct } \\
\text { exposure to the crisis during the time } \\
\text { of the crisis. } \\
\text { 2. The likelihood of systemic failure } \\
\text { based on a structural credit risk model } \\
\text { and distances to default. } \\
\text { 3. Bank default probabilities based on } \\
\text { equity option prices. }\end{array}$ & $\begin{array}{l}\text { Micro approach. The difference } \\
\text { between average pre-crisis and } \\
\text { post-crisis probabilities for banks } \\
\text { with no direct exposure to the } \\
\text { crisis. }\end{array}$ & $\begin{array}{l}\text { Market value, debt, } \\
\text { deposits, and asset } \\
\text { volatility. }\end{array}$ \\
\hline $\begin{array}{l}\text { Brownlees \& Engle } \\
\text { (2012) }\end{array}$ & $\begin{array}{l}\text { Marginal expected capital shortfall } \\
\text { during a crisis. }\end{array}$ & $\begin{array}{l}\text { Expected capital shortage of a } \\
\text { firm during a crisis as indication } \\
\text { for the institutions' contribution } \\
\text { to system wide capital shortage. }\end{array}$ & $\begin{array}{l}\text { Leverage, size and } \\
\text { marginal expected } \\
\text { shortfall. }\end{array}$ \\
\hline De Jonghe (2010) & $\begin{array}{l}\text { The tail beta i.e., the probability of } \\
\text { a decrease in a bank's stock price in } \\
\text { the case of a banking index crash } \\
\text { computed via extreme value analysis. }\end{array}$ & $\begin{array}{l}\text { Micro approach. The probability } \\
\text { computed for each institution. }\end{array}$ & $\begin{array}{l}\text { Non-traditional } \\
\text { banking activities, } \\
\text { bank size, bank } \\
\text { capitalization. }\end{array}$ \\
\hline $\begin{array}{l}\text { Drehmann \& Tarashev } \\
\text { (2013) }\end{array}$ & $\begin{array}{l}\text { Expected shortfall based on Shapley } \\
\text { values. }\end{array}$ & $\begin{array}{l}\text { Two attribution methods based } \\
\text { on Shapley values: to what extent } \\
\text { a bank generates a shock and } \\
\text { to what extent it propagates } \\
\text { existing shocks besides } \\
\text { generating ones. }\end{array}$ & n.a. \\
\hline
\end{tabular}


Table 2. (Continued)

\begin{tabular}{|c|c|c|c|}
\hline Authors & Systemic risk measure & $\begin{array}{l}\text { Systemic risk attribution to } \\
\text { individual institutions }\end{array}$ & $\begin{array}{l}\text { Systemic risk } \\
\text { determinants }\end{array}$ \\
\hline $\begin{array}{l}\text { Huang, Zhou \& Zhu } \\
\text { (2010) }\end{array}$ & $\begin{array}{l}\text { Insurance cost against losses in a } \\
\text { banking system i.e., a measure including } \\
\text { expected default risk of single banks, } \\
\text { risk premia and their correlated defaults } \\
\text { based on banks'CDS spreads and equity } \\
\text { price co-movements, respectively } \\
\text { applied to a portfolio credit risk model. }\end{array}$ & $\begin{array}{l}\text { Computed for each bank } \\
\text { individually. }\end{array}$ & $\begin{array}{l}\text { Expected default } \\
\text { risk, CDS spreads } \\
\text { and equity price } \\
\text { co-movements. }\end{array}$ \\
\hline $\begin{array}{l}\text { Puzanova \& Düllmann } \\
\text { (2013) }\end{array}$ & $\begin{array}{l}\text { Expected extreme loss in banks' } \\
\text { liabilities measured by expected } \\
\text { shortfall and value at risk based on } \\
\text { a structural credit risk model. }\end{array}$ & $\begin{array}{l}\text { Marginal expected shortfall } \\
\text { contributions based on Euler } \\
\text { allocation principle. }\end{array}$ & $\begin{array}{l}\text { Capitalization, } \\
\text { correlation of } \\
\text { assets, systemic } \\
\text { size, banking } \\
\text { concentration. }\end{array}$ \\
\hline $\begin{array}{l}\text { Tarashev, Borio, \& } \\
\text { Tsatsaronis (2010) }\end{array}$ & $\begin{array}{l}\text { System wide Value at Risk and expected } \\
\text { shortfall based on Shapley values. }\end{array}$ & $\begin{array}{l}\text { Two attribution procedures } \\
\text { based on Shapley values: the } \\
\text { contribution of single institutions } \\
\text { to systemic risk and their } \\
\text { participation in systemic events. }\end{array}$ & $\begin{array}{l}\text { Relative size, } \\
\text { probability of } \\
\text { default, exposure } \\
\text { to common risk. }\end{array}$ \\
\hline $\begin{array}{l}\text { Vallascas \& Keasey } \\
\text { (2012) }\end{array}$ & $\begin{array}{l}\text { Distance to default and tail measure } \\
\text { conditional on the occurrence of } \\
\text { market decline. } \\
\text { The default risk is proxied by Merton's } \\
\text { distance to default model. }\end{array}$ & $\begin{array}{l}\text { Micro approach- reactions to } \\
\text { shifts in the banking sector } \\
\text { conditions computed for each } \\
\text { bank based on the Merton's } \\
\text { distance to default model. }\end{array}$ & $\begin{array}{l}\text { Leverage ratio, } \\
\text { liquidity } \\
\text { requirements, } \\
\text { bank size, the share } \\
\text { of non-interest } \\
\text { income and asset } \\
\text { growth. }\end{array}$ \\
\hline
\end{tabular}

\section{Conclusions}

The latest financial crisis reveals many weaknesses of bank risk modeling. Due to their pro-cyclicality and lack of accounting for tail events, the commonly used VaR models are misleading. The economic literature proposes alternative risk measures e.g., the expected shortfall or generalized spectral measures. Each of these measures has its advantages and drawbacks; nevertheless, the expected shortfall and other spectral measures are viewed as more conservative in risk assessment and are favored by regulators.

The choice of the risk measurement method is crucial because regulators and bank managers base their risk models on these measures. The respective versions of the Basel Accords offer evolving risk models that attempt to resolve the problems of arbitrary model choices by banks, portfolio invariance issues, and the various treatment of banking and trading books. A challenge that still lies ahead for regulators is compensating for the drawbacks of the applied measures. An issue left to resolve is the pro-cyclicality in risk modeling and the improvement of the techniques of stress testing.

A substantial challenge of the financial crisis for risk modeling is also the revealed fallacy of composition in banking, which highlights the need for risk modeling from a systemic point of view in addition to an individual bank's perspective. Systemic risk models al- 
low regulators to account for spillovers and correlated exposure among banks that can destabilize the whole banking system during times of market distress.

While the evolving risk measures and models are gradually being included in the banking regulatory frameworks, there are many systemic risk factors which have not yet been subjected to regulations. The challenge of adapting the regulations to changing risk profiles of banks and banking systems lies still ahead.

\section{References}

Acerbi, C., Tasche, D. (2002). On the coherence of expected shortfall. Journal of Banking and Finance, 26 (7), 1487-1503.

Acharya, V., Engle, R., \& Richardson, M. (2012). Capital shortfall: a new approach to ranking and regulating systemic risks. American Economic Review: Papers \& Proceedings, 102 (3), 59-64.

Acharya, V., Pedersen, L., Philippon, T., \& Richardson, M. (2010). Measuring systemic risk (Working Paper No. 1002). Federal Reserve Bank of Cleveland.

Adrian, T. \& Brunnermeier, M. (2011). CoVaR (Staff Report No. 348). Federal Reserve Bank of New York.

Altman, E. (1968). Final ratios, discriminant analysis and the prediction of corporate bankruptcy. Journal of Finance, 23 (4), 589-609.

Bartram, S. M., Brown, G. W., \& Hund, J. E. (2007). Estimating systemic risk in the international financial system. Journal of Financial Economics, 86 (3), 835-869.

BCBS (2009a). Guidelines for computing capital for incremental risk in the trading book. Basel, Bank for International Settlements. Retrieved from http://www.bis.org/publ/bcbs159.pdf

BCBS (2009b). Revisions to the Basel II market risk framework. Bank for International Settlement. Retrieved from http://www.bis.org/publ/bcbs158. pdf

BCBS (2011). Messages from the academic literature on risk measurement for the trading book (Working Paper No. 19). Bank for International Settlement. Retrieved from http://www.bis.org/publ/ bcbs_wp19.pdf

BCBS (2012). Fundamental review of the trading book. Basel, Bank for International Settlements. Retrieved from http://www.bis.org/publ/bcbs219.pdf
Blundell-Wignall, A., \& Atkinson, P. (2010). Thinking beyond Basel III: necessary solutions for capital and liquidity. OECD Journal: Financial Market Trends, 1, 1-23.

Brownlees, C. T., Engle, R. (2012). Volatility, correlation and tails for systemic risk measurement. Available at SSRN: http://ssrn.com/abstract=1611229.

Chen, J. (2014). Measuring market risk under the Basel accords: VaR, stressed VaR, and expected shortfall. Aestimatio, The IEB International Journal of Finance, 8, 184-201.

Damodaran, A. (2010), The value at risk. Available at: http://people.stern.nyu.edu/adamodar/

Danielsson, J., Shin, H., Zigrand, J. (2013). Endogenous and systemic risk. In J. Haubrich \& Lo (Eds.), Quantifying systemic risk (pp. 73 - 94). Chicago, IL: University of Chicago Press.

De Jonghe, O. (2010). Back to the basics in banking? A micro-analysis of banking system stability. Journal of Financial Intermediation, 19 (3), 387-417.

Drehmann, M. \& Tarashev, N. (2013) Measuring the systemic importance of interconnected banks. Journal Financial Intermediation, 22 (4), 586-607.

EBA (2012). EBA guidelines on stressed value at risk (Stressed VaR). EBA/GL/2012/2. London, EBA. Retrieved from https://www.eba.europa.eu/documents/10180/104547/EBA-BS-2012-78--GL-onStressed-VaR-.pdf

Gropp, R., Vesala, J., \& Vulpes, G. (2006). Equity and bond market signals as leading indicators of bank fragility. Journal of Money, Credit and Banking, 38 (2), 399-428.

Huang, X., Zhou, H., \& Zhu, H. (2010). Assessing the systemic risk of a heterogenous portfolio of banks during the recent financial crisis (Woking Paper No. 296). Bank for International Settlements.

Inanoglu, H., Jacobs, M., \& Karagozoglu, A. (2014), Bank capital and new regulatory requirements for risks in trading portfolios. The Journal of Fixed Income, 23 (4), 71-88.

Iyer, R., Peydró, J. L. (2009). Interbank contagion at work: evidence from a natural experiment. Review of Financial Studies, 24 (4), 1337-1377.

Larsen, N., Mausser, H., Uryasev, S. (2002). Algorithms For optimization of value-at-risk. In P. M. Pardalos, \& V. K. Tsitsiringos (Eds.), Financial engineering, e-commerce and supply chain (pp. 19-46). Norwell, 
MA: Kluwer Academic Publishers. Research Report, ISE Dept., University of Florida, available at: www. ise.ufl.edu/uryasev/wp_VaR_minimization.pdf

Mansi, S. A., Maxwell, W. F., Zhang A. (2010). Bankruptcy prediction models and the cost of debt. Journal of Fixed Income, 21 (4), 25-42.

Merton, R. (1974). On the pricing of corporate debt: the risk structure of interest rates. Journal of Finance, 29 (2), 449-70.

Ohlson, J. (1980). Financial ratios and the probabilistic prediction of bankruptcy. Journal of Accounting Research, 18 (1), 109-131.

Patro, D. K., Qi, M., Sun, X. (2013). A simple indicator of systemic risk. Journal of Financial Stability, 9 (1), 105- 116.

Puzanova, N., \& Düllmann, K. (2013). Systemic risk contributions: a credit portfolio approach. Journal of Banking \& Finance, 37 (4), 1243-1257.

Rockafellar, R. T. \& Uryasev, S. (2002). Conditional value-at-risk for general loss distributions. Journal of Banking \& Finance, 26 (7), 1443-1471.

Slovik, P. (2012), Systemically important banks and capital regulation challenges (Working Papers No. 916). OECD Publishing.

Tarashev, N., Borio, C., \& Tsatsaronis, K. (2010). Attributing systemic risk to individual institutions. Methodology and policy applications (Working Papers No. 308). Bank for International Settlements.

Vallascas, F., \& Keasey, K. (2012). Bank resilience to systemic shocks and the stability of banking systems: Small is Beautiful. Journal of International Money and Finance, 31 (6), 1745-1776.

Yamai, Y., \& Yoshiba, Y. (2005). Value-at-risk versus expected shortfall: a practical perspective. Journal of Banking and Finance, 29 (2), 997-1015. 
